Chirurgia (2017) 112: 97-109

No. 2, March - April

Copyright@ Celsius

http://dx.doi.org/10.21614/chirurgia.112.2.97

\title{
Pancreatic Cystic Lesions: Diagnostic, Management and Indications for Operation. Part I
}

\author{
Ferdinand Bauer \\ Director of Radiology Clinics in Kaufbeuren - Landsberg - Füssen, Germany
}

Corresponding author:

Ferdinand Bauer, MD

Radiology Specialist

Director of Radiology Clinics in

Kaufbeuren - Landsberg - Füssen, Germany

E-mail: Ferdinand.Bauer@radiologie-kaufbeuren.de

\section{Abbreviations:}

CEA: carcinoembryonic antigen;

CT: computed tomography;

ERCP: endoscopic retrograde

cholangio-pancreatography;

FNA: fine-needle aspiration;

IPMNs: intraductal papillary mucinous neoplasms;

MCN: mucinous cystic neoplasms;

MDCT: multidetector computed

tomography;

MRCP: magnetic resonance

cholangio-pancreatography;

MRI: magnetic resonance imaging;

MRT: magnetic resonance tomography

PCLs: pancreatic cystic lesions;

PCN: pancreatic cystic neoplasms;

SCNs: serous cystic neoplasms;

Received: 31.01 .2017

Accepted: 28.02.2017

\section{Rezumat}

Neoplaziile chistice pancreatice: diagnostic, management și indicațile pentru interventiile chirurgicale. Partea I

În ultimele trei decenii am observat o creştere a frecvenței depistării şi evaluării leziunilor chistice pancreatice (PCL). Acestea prezintă o paletă variată de trăsături imagistice şi clinice. Diagnosticul şi diferențierea leziunilor chistice pancreatice este deosebit de importantă, din cauza riscului concret de malignizare. Principalul motiv al acestei lucrari este conştientizarea existenței acestor leziuni şi folosirea extinsă a modalităților imagistice cu secțiuni transversale, tehnică aflată într-o continuă dezvoltare (1). De obicei, PCL sunt diagnosticate din întâmplare în timpul investigării unor dureri abdominale independente şi nespecifice folosind proceduri imagistice obişnuite, CT sau IRM. Leziunile chistice pancreatice reprezintă o colecție eterogenă histologică, care poate avea un spectru larg de diagnostice de la complet benign la potențial malign, la carcinom in situ şi până la invaziv (2,3). În 1978, Compagno şi Oertel au fost primii care au observat distincția crucială între neoplaziile chistice seroase şi mucinoase ale pancreasului şi au explicat importanța identificării neoplaziilor mucinoase din cauza potențialului lor malign latent sau evident $(4,5)$. De atunci, interesul pentru PCL a crescut semnificativ, mai ales după ce a fost identificată importanța şi prevalența neoplaziilor papilare mucinoase intraductale (IPMN). In prezent, PCL reprezintă o provocare frecventă şi dificilă în practica clinică, datorită creşterii detectării acestora la pacienți asimptomatici şi a lipsei de înțelegere a aspectelor care tin de comportamentul biologic al acestor neoplazii. Diferențele importante în ceea ce priveşte rezultatul lor final şi identificarea acestora tot mai frecventă au plasat neoplaziile în atenția chirurgilor, anatomopatologilor, gastroenterologilor, 
radiologilor şi medicilor oncologi. Managementul pacienților cu PCN este o provocare şi variază considerabil în funcție de subtipurile acestor tumori. Tratamentul variază de la rezecție, în cazul tumorilor maligne, la rezecție şi / sau urmărire, în cazul leziunilor premaligne, la simpla monitorizare, în cazul leziunilor benigne sau fără simptome. În aceste condiții, o clasificare exactă a PCN devine crucială. Luarea deciziilor terapeutice şi clasificarea se bazează în principal pe simptomele prezente şi pe rezultatele investigațiilor imagistice, cel mai des fără analiza histologică. Identificarea trăsăturilor suspecte care indică o malignitate potențială sau sigură este extrem de importantă pentru alegerea unui tratament potrivit. Riscul supratratării (pancreatectomie care nu este necesară) trebuie comparat prudent cu riscul subtratării (ratarea şansei de a vindeca o afecțiune malignă sau premalignă potențial vindecabilă) (6).

Cuvinte cheie: leziunile chistice pancreatice (PCL), neoplazii chistice pancreatice (PCN), neoplazii chistice seroase $(\mathrm{SCN})$, neoplazii chistice mucinoase $(\mathrm{MCN})$, neoplazii papilare mucinoase intraductale (IPMN), benign, premalign, malign

\begin{abstract}
We notice an increasing frequency in the detection and evaluation of pancreatic cystic lesions (PCLs) over the last three decades. They show awide spectrum of imaging and clinical features. The diagnosis and discrimination of these lesions are very important because of the risk for concurrent or later development of malignancy. The main reason is the increased awareness of these lesions and the extensive use of cross-sectional imaging, an always improving technique (1). Commonly, PCLs are diagnosed incidentally during investigation for often unrelated and nonspecific abdominal complaints using state-of-the art abdominal imaging (CT, MRT). The term PCN denotes a histologically heterogeneous collection of neoplasms showing a wide spectrum of diagnoses, ranging from completely benign to potentially malignant, to carcinoma in situ, to frankly invasive and malignant $(2,3)$. In 1978, Compagno and Oertel were the first to recognize the crucial distinction between the serous and the mucinous cystic neoplasms of the pancreas by explaining the importance of identifying the mucinous neoplasms because of their overt or latent malignant potential $(4,5)$. Since then, the interest in PCLs increased markedly, especially so with the recognition of the importance and prevalence of intraductal papillary mucinous neoplasms (IPMNs). Nowadays, PCLs represent a common and often difficult challenge in clinical practice, because of the increase in their detection in asymptomatic patients and our still immature understanding of some aspects of their biologic behavior. Their important differences regarding their outcome and the fact of being increasingly often identified has put a special focus on these neoplasms by surgeons, pathologists, gastroenterologists, radiologists, and oncologists alike. Management of patients with PCNs can be challenging and varies considerably among the various subtypes of PCNs. Their treatment ranges from resection of malignant lesions, to resection and/or surveillance in the case of premalignant lesions, to simple observation in the case of benign or indolent lesions. Under these circumstances, the accurate classification of PCNs becomes crucial. Therapeutic decision making and classification rely mainly on the presenting symptoms and radiologic findings, often without actual histologic tissue. It is of extreme importance to identify suspicious features indicating potential or certain malignancy in order to select the appropriate treatment. The risk of overtreatment (unnecessary pancreatectomy) should he balanced carefully with the risk of under treatment (missing the opportunity to cure a potentially curable malignant or premalignant disease) (6).
\end{abstract}

Key words: PCNs, SCN, MCN, IPMN, benign, premalignant, malignant 


\section{Classification of pancreatic cystic lesions}

According to Brugge (3), PCLs may be classified simply into two main classes such as nonneoplastic (i.e. pseudocysts) and neoplastic cysts (Fig. 1). Neoplastic cysts are more commonly defined as pancreatic cystic neoplasms (PCNs). It is important to distinguish nonneoplastic cysts/pseudocysts from neoplastic or non-mucinous from mucinous cysts because the latter are considered being premalignant lesions. This approach starts by distinguishing between benign and potentially malign cases. In general, non-neoplastic cysts account up to $80 \%$ of all PCLs. PCN-Rate increases significantly with age (7).

Diagnostic methods, management algorithms and treatment options of PCL shave been developed intensively in recent years. Classification of pancreatic cystic lesions can also be easily visualized based on their typical morphology and location (Fig. 2).

The classification of cystic lesions is easy and efficient if we use following standard scheme - Fig. 1.

The first step is to establish whether the lesion is a pseudocyst or a cystic neoplasm. Pseudocysts are benign, easy to identify, and by far the most frequent cystic lesion of the pancreas $(3,8)$. If it is not a pseudocyst, then it must be a cystic neoplasm, which may be serous or mucinous. Serous cystic neoplasms are mainly benign, while mucinous neoplasms have an important malignancy potential.

We need such an easy and efficient classification scheme because:

- Cystic pancreatic lesions are identified with increasing frequency. Most of these cysts are detected incidentally, are benign or have a low level of malignancy (9).

- Characterization and management of these lesions is a challenge, because the morphology of benign cysts overlaps significantly with the morphology of premalignant cysts.

- These lesions are often difficult to differentiate. In such situations we need monitoring and management guidelines $(10,11)$.

- Recommended imagistic examination both for characterization and monitoring of pancreatic cystic lesions are: MDCT,

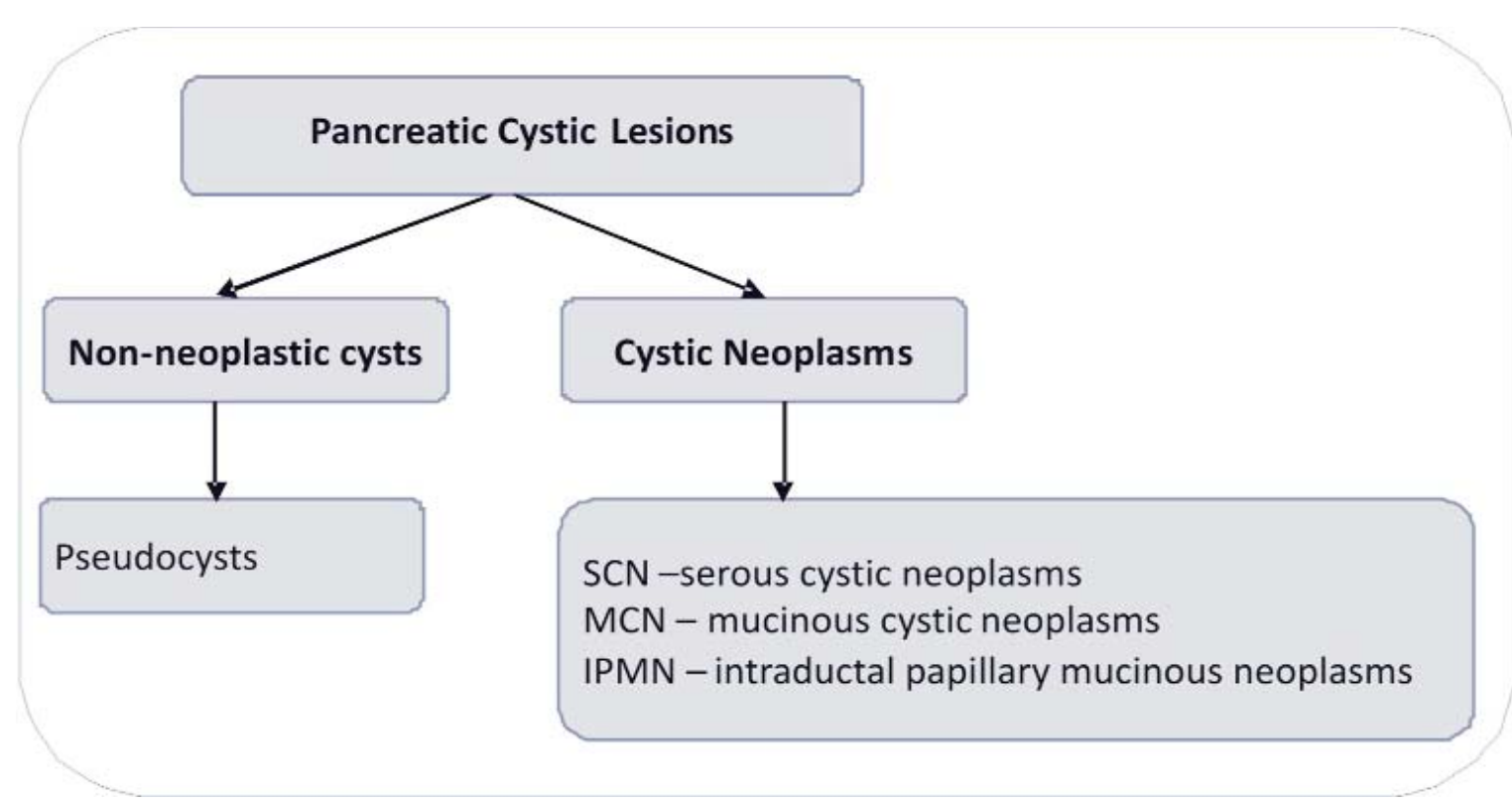

Figure 1. Classification of pancreatic cystic lesions - stage 1: Differentiate between pseudocysts/non-neoplastic cyst (e.g. after pancreatitis) and cystic neoplasms. Cystic neoplasms may be serous - potentially benign (SCN), mucinous outside the pancreatic duct (MCN), or intraductal (IPMN). Mucinous neoplasms have malignant potential 


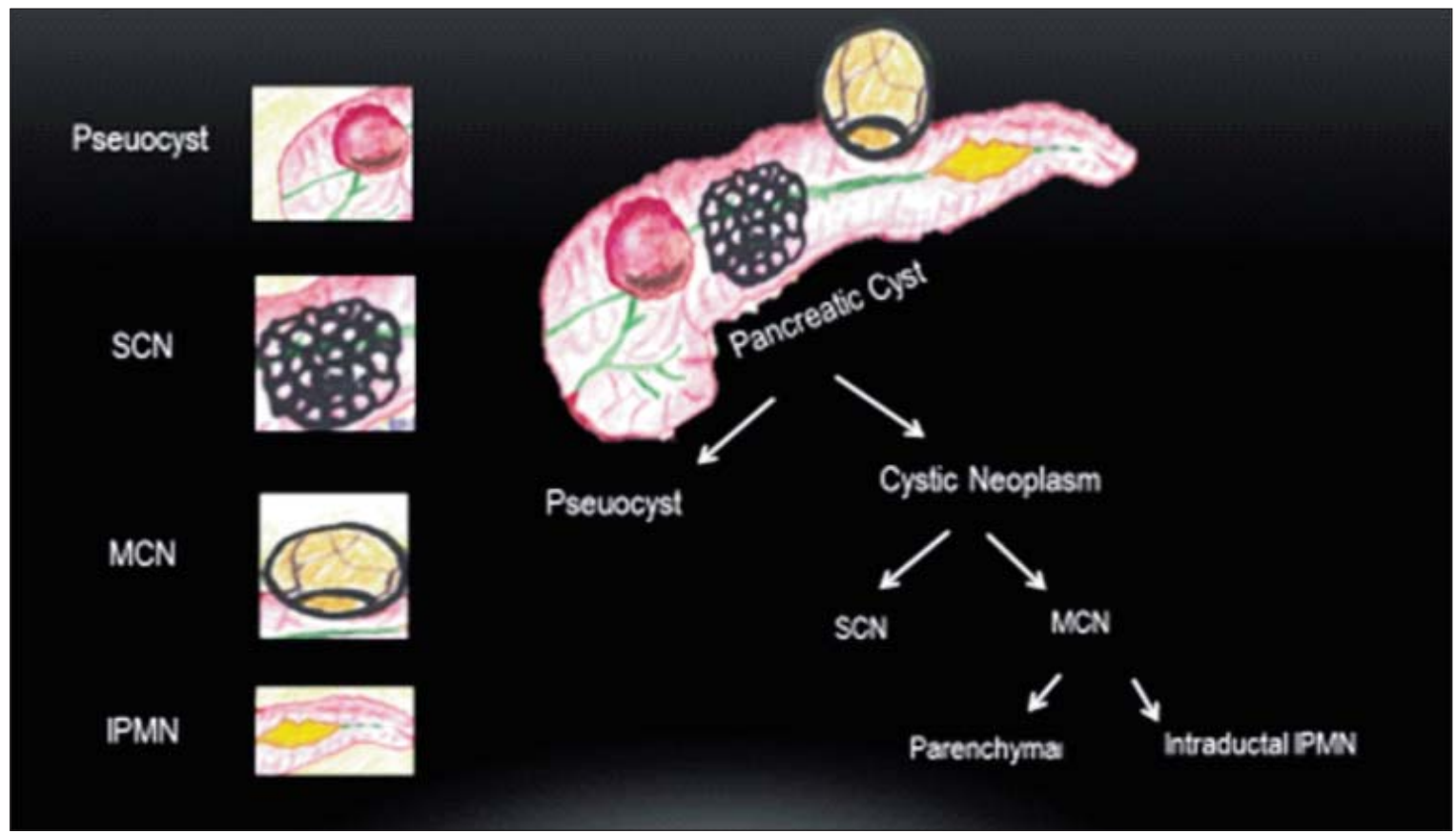

Figure 2. Visual classification of pancreatic cystic lesions PCLs showing typical aspect of non-neoplastic cysts (pseudocysts) and major pancreatic cystic neoplasms (PCNs)

MRT, MRCP, and EUS guided fine-needle aspiration (FNA).

\section{Pancreatic pseudocyst}

Pseudocysts are the most common pancreatic cystic lesion $(3,8)$. A unilocular cyst with a background of acute or chronic pancreatitis is almost always a pseudocyst (Fig. 3)(12). A pseudocyst may be accompanied by mild symptoms like abdominal pain, early satiety, nausea and vomiting (3), and present chemical and imagistic typical pancreatitis signs (13). It develops usually after 4-6 weeks of an episode of acute pancreatitis.Its size may vary from $2-20 \mathrm{~cm}(3)$.

\section{Imaging}

Common location of pseudocysts is the fatty tissue adjacent to the pancreas or, less commonly, inside the pancreatic tissue with infiltration of the mentioned fatty tissue. It is usually a unilocular cyst situated outside the pancreatic duct, with no epithelial lining, but which may develop a well-defined thin wall of

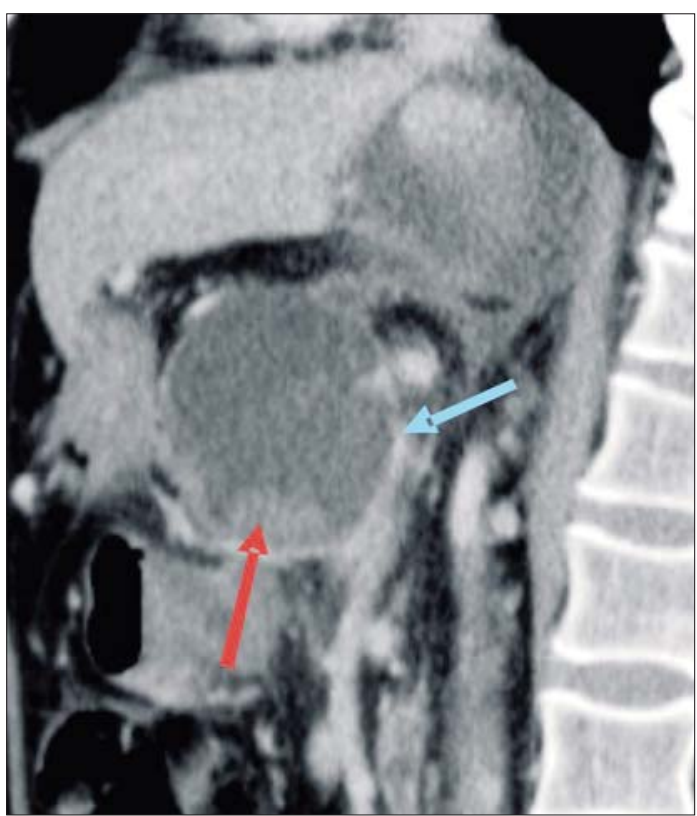

Figure 3. CT presenting a unilocular, $7 \mathrm{~cm}$ large pancreatic pseudocyst with debris (red arrow) which settled down on the bottom of the cyst. Content of debris: necrotic tissue, pancreatic enzymes and blood. We observe a well-defined thin wall (blue arrow) of granulated or fibrous tissue (no epithelial lining) 


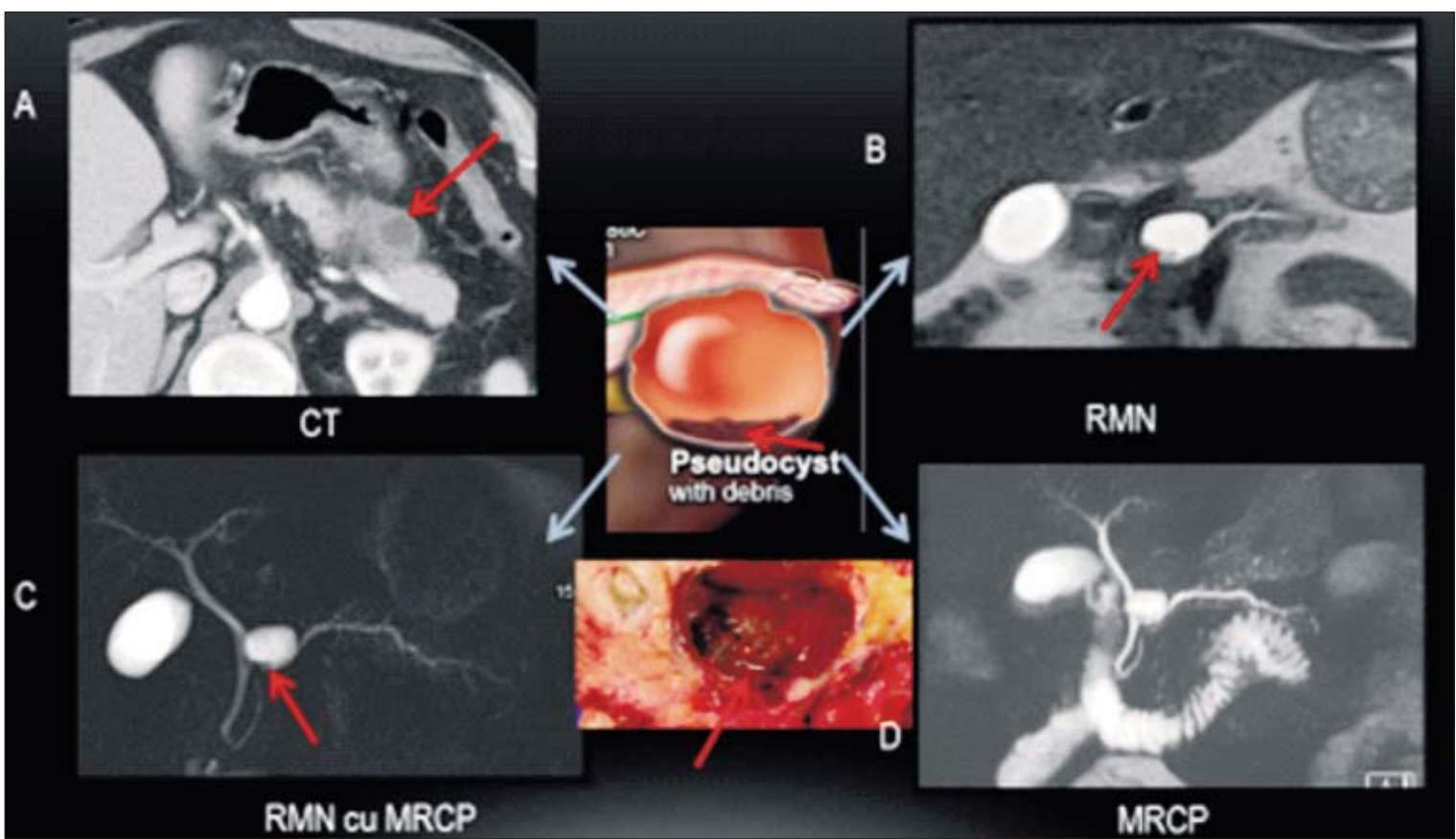

Figure 4. Detection and characterization of small pseudocysts with different imaging techniques: $(\mathbf{A})-\mathrm{CT}$ is good for detection, but insufficient for characterization. (B) - MRT and (C, D) - MRCP allow the characterization of pseudocysts respective to their relation to the pancreatic duct. The specimen and MRT show the accumulation of pancreatic enzymes, blood and necrotic tissue (debris)

granulated tissue or fibrous tissue $(3,8)$. It is filled with fluid of low viscosity, and debris made of necrotic tissue, pancreatic enzymes and blood, which settle on the base of the cyst (Fig. 3). CT is a good enough imaging method for detection (Fig. 4A) (14), but MRT (Fig. 4 B) / MRCP is definitely the method of choice for characterization $(8,14,15)$, due to its ability of depicting the relation of the pseudocyst to the pancreatic duct (Fig. $4 C, D$ ).

On the other hand, CT shows pancreatic modifications due to chronical disease pancreatitis, e.g. calcifications, and facilitates surgical interventions on pseudocysts, as in the case of major infections. In such situations, an examination in the portal venous phase is sufficient. The pseudocyst may be treated with endoscopic ultrasound-guided fine needle aspiration, or surgical resection. Non-symptomatic cysts delimited by fine walls may be kept under observation on CT or MRT, especially in case of very small cysts.

\section{Management}

The first step in the management of pseudo- cysts is to prove with a fair enough confidence that we are dealing with a pseudocysts, as their treatment differs considerably from cystic neoplasms. Therefore, in case of doubt EUS guided fine-needle aspiration and subsequent cyst fluid analysis differentiates between the two lesion groups in $90 \%$ of patients (16). Consequently, a high concentration of amylase indicates a connection with the main pancreatic duct, and so brings the pseudocyst in discussion. Low levels of CEA favor pseudocyst diagnosis over mucinous cystic neoplasms and IPMNs (3). Cytological examination of the aspirated fluid of a pseudocyst should not present evidence of epithelial cells, otherwise we are rather dealing with a cystic neoplasm (17). The presence of granulocytes in the aspirated fluid is suggestive of an acute infection.

According to Brugge (3), simple, peripancreatic fluid collections that arise during acute pancreatitis usually resolve spontaneously. Without a constant source of fluid from a ductal epithelium, pseudocysts may spontaneously resolve. Small pseudocysts, 


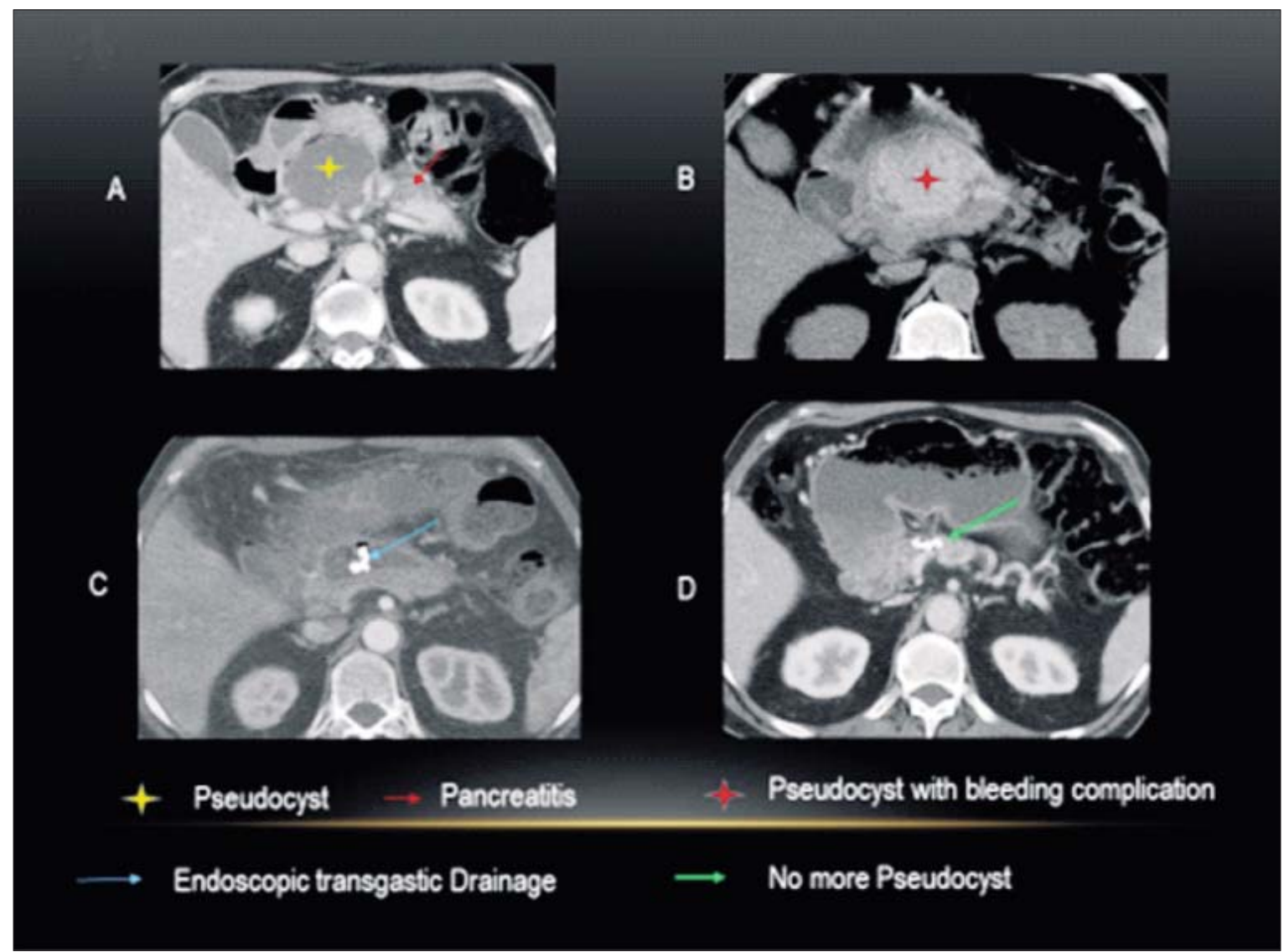

Figure 5. (A) Pseudocyst 6 weeks after an episode of acute pancreatitis. (B) Bleeding complication after 7 weeks. (C) Reduction of the pseudocyst after endoscopic transgastric drainage and stenting from the Wirsung duct (not visible in CT); (D) Complete resorption of the pseudocyst after 3 months

less than $4 \mathrm{~cm}$ in diameter, often resolve and are rarely associated with complications, although larger cysts are generally more likely to become symptomatic or cause complications (18) (Fig. 5B). Spontaneous resolution of pseudocysts takes place through drainage into the GI tract or the pancreatic duct (Fig. 5C). Long-term observational studies showed that complication in less than $10 \%$ of cases. The main indications for drainage of pseudocysts are persistence or complications (infection, bleeding, gastric outlet or biliary obstruction) (3) (Fig. 5B). Forty percent of the pseudocysts less than $6 \mathrm{~cm}$ and approximately the half of the pseudocysts larger than $6 \mathrm{~cm}$ will require drainage because of complications or persistence (18).

Drainage of pancreatic pseudocysts may be accomplished with a variety of procedures (19).
A drainage catheter may be placed percutaneously into the fluid cavity under the CT/US guidance, and fluid is drained into an external collection system. The short-term success rate of this relatively simple technique is very high but it has a high risk of infections and creates significant patient discomfort. Surgical drainage of pseudocysts is performed by providing a large anastomosis between the pseudocyst cavity and the stomach or small bowel. Overall success rate of surgical drainage is very high but it is an invasive technique with high complication rates. It should be reserved for those patients that cannot tolerate or failed other drainage methods (3).

Endoscopic drainage technique is the current preferred method $(20,21)$. It may be accomplished with either a transpapillary approach with ERCP or with a direct, transgastric or 


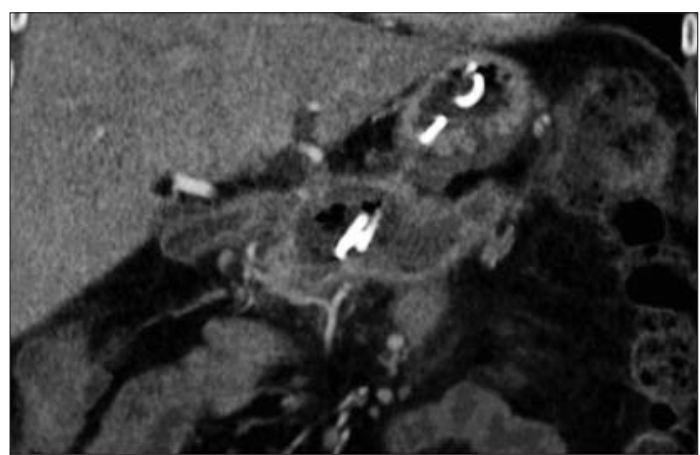

Figure 6. Transgastric drainage under EUS

duodenal approach. The transpapillary approach (Fig. 5C) has been proved to be useful when the pseudocysts communicates with the main pancreatic duct (16). A direct drainage through the stomach or duodenal wall (Fig. 6) makes sense when the pseudocyst is located adjacently to the gastroduodenal wall. Contraindications to drainage are cyst wall thickness more than $1 \mathrm{~cm}$, or presence of large intervening vessels or varices (3). These characteristics may be detected using EUS. Overall, the complication rate of elective endoscopic drainage is about 13\%, with success rates of more than 90\% (Fig. 5D) and recurrence rates of less than 10\% (3).

In case of incidental pancreatic cysts, fore any surgical operation, it is recommended to perform cyst fine-needle aspiration for a better differential diagnostic of pseudocysts from cys ${ }^{-}$ tic neoplasms. This differentiation is essential for correct therapeutic decision. Consequently, the diagnostic cardinal points are: anamnesis, clinical examination, morphology, evolution and aspiration (Fig. 7).

Several unilocular cysts are usually pseudocysts resulting from a previous pancreatitis. In case of a unilocular finding with lobulated surface situated in the pancreas head, we must consider the differential diagnostic of a mucinous cystic neoplasm. Irregular thickening of the cystic walls indicate a rather aggressive biological behavior.

\section{Major pancreatic cystic neoplasms}

Increasing detection of pancreatic cystic lesions led also to a higher frequency of detection of pancreatic cystic neoplasms. Consequently, although pancreatic cystic lesions are relatively rare, and the vast majority of these lesions are

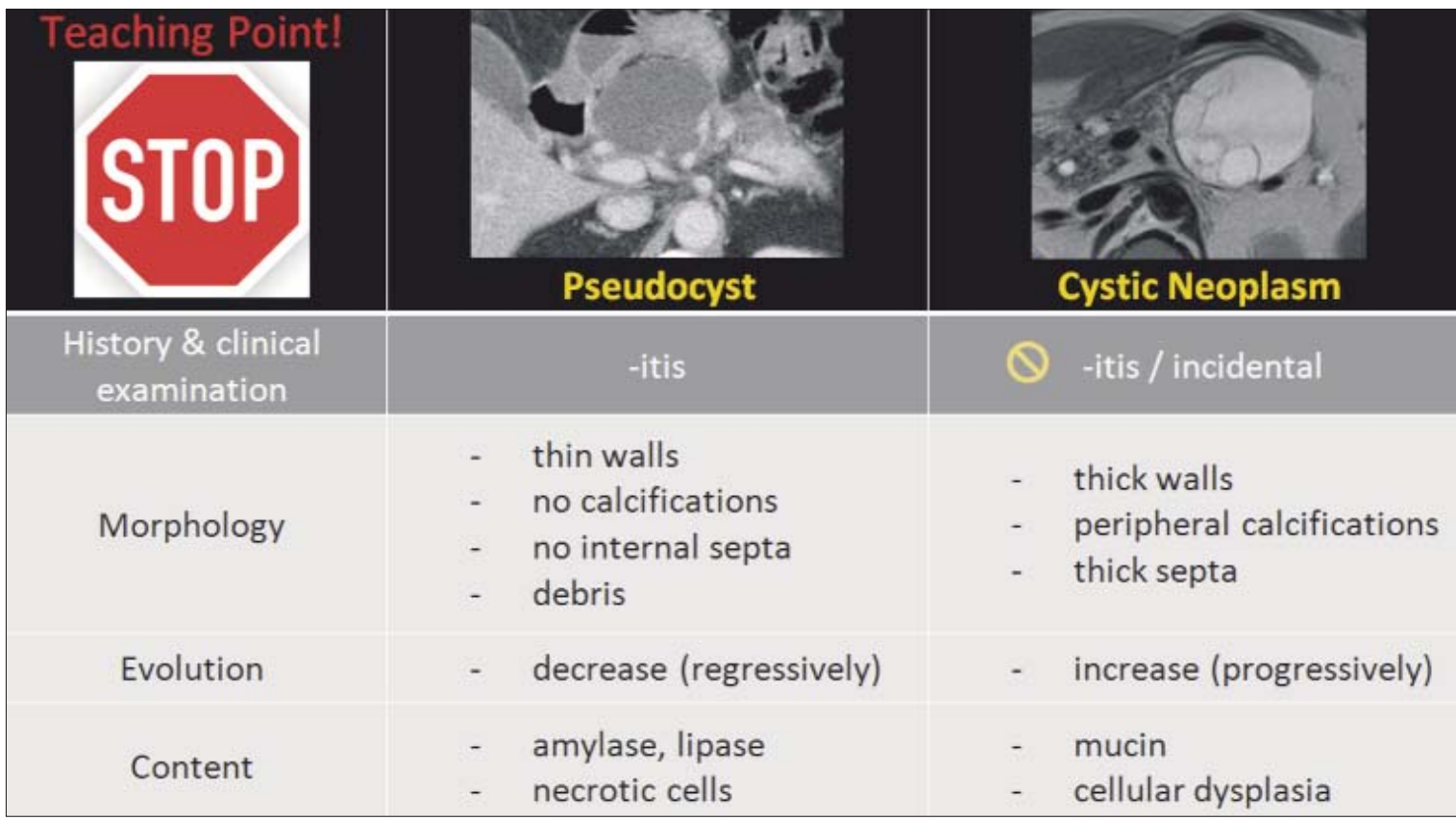

Figure 7. Guidelines for thediagnostic of cystic lesions 
benign (22), accurate characterization of a cystic lesion of the pancreas is crucial in determining the appropriate management (imaging follow-up or operative excision). Recent advances in imaging technology increased the accuracy of preoperative diagnosis of PCLs. In many cases, cystic pancreatic neoplasms have characteristic morphologic imaging features which can suggest or confirm a diagnosis; however, the proper evaluation of these lesions can often be difficult due to morphologic overlap at imaging between benign and malignant forms (9).

\section{Imaging modalities of pancreatic cystic lesions (PCLs)}

Cross-sectional imaging continues to be the main instrument for detection and assessment of cystic pancreatic tumors.

1. Transabdominal ultrasonography (US) can detect PCLs, but its limited spatial resolution and soft-tissue contrast are not good enough for a correct evaluation of cystic neoplasms of the pancreas.

2. Multidetector computed tomography (CT) and magnetic resonance imaging (MRI) are the most common radiologic methods used for characterization of these lesions. Despite many authors favoring MRI due to its better contrast between fluid and soft tissue $(23,24)$, recent studies suggest that both MDCT and MRI provide high-quality images of cystic pancreatic lesions with comparable diagnostic accuracy (25). Although the accuracy of these methods ranges from 40 to $60 \%$ in providing the correct histologic diagnosis of cystic lesions of the pancreas (9), Visser et al. (25) found that multidetector CT and MRI had an accuracy of $76-82 \%$ and $85-91 \%$ respec- $^{-}$ tively in establishing the diagnosis of malignancy in cystic pancreatic masses. Advanced MRI techniques, such as DWI, and $\mathrm{ADC}$ measurements proved to be less helpful in differentiating neoplastic from non-neoplastic pancreatic cysts than expected (24).

3. Magnetic resonance cholangiopancreato- graphy (MRCP) is a non-invasive diagnostic method which uses the inherent contrast of the fluid-filled ducts to generate images of the biliary system and pancreatic duct. It is based on a heavily T2weighted pulse sequence which shows static or slow-moving fluid-filled structures, such as the bile and pancreatic ducts, appearing at greatly high signal intensity, whereas the surrounding structures generate little signal resulting in increased duct-to-background contrast. It provides an excellent visualization of the pancreatic duct (Fig. 8C) detecting even the smallest communication between a PCL and the pancreatic ductal system (23). This finding on MRCP may be more specific than ERCP, because filling of side branch ducts at the time of ERCP may be obscured by intraductal plugs of mucus (26). Thereby, MRCP may be helpful in differentiating a primary MCN of the pancreas from a branch-duct-type IPMN by showing the absence or presence, respectively, of a ductal communication (27). Moreover, internal nodular components in a main-duct-type IPMN as well as concomitant side branch lesions of IPMN may be detected on MRCP (26).

\section{A. Serous cystic neoplasms (SCNs)}

\section{Incidence}

This class includes pancreatic cystic neoplasms which are more frequently found in older women (2) "category granny", and which are mainly benign (malignancy risk extremely low: 0-1.2\%) $(6,9)$.

\section{Morphology}

The most common appearance $(70 \%$ of the cases) of SCN is as lobulated lesion consisting of numerous cysts (more than 6) varying from a few millimeters to $2 \mathrm{~cm}$ in diameter (but typically less than $1 \mathrm{~cm})(2,9,28)$ (Fig. 8). This appearance was first described 1978 by Compagno and Oertel (4) as "honeycomb". A central fibrous scar that may be calcified is seen up to $30 \%$ of cases and is considered to 


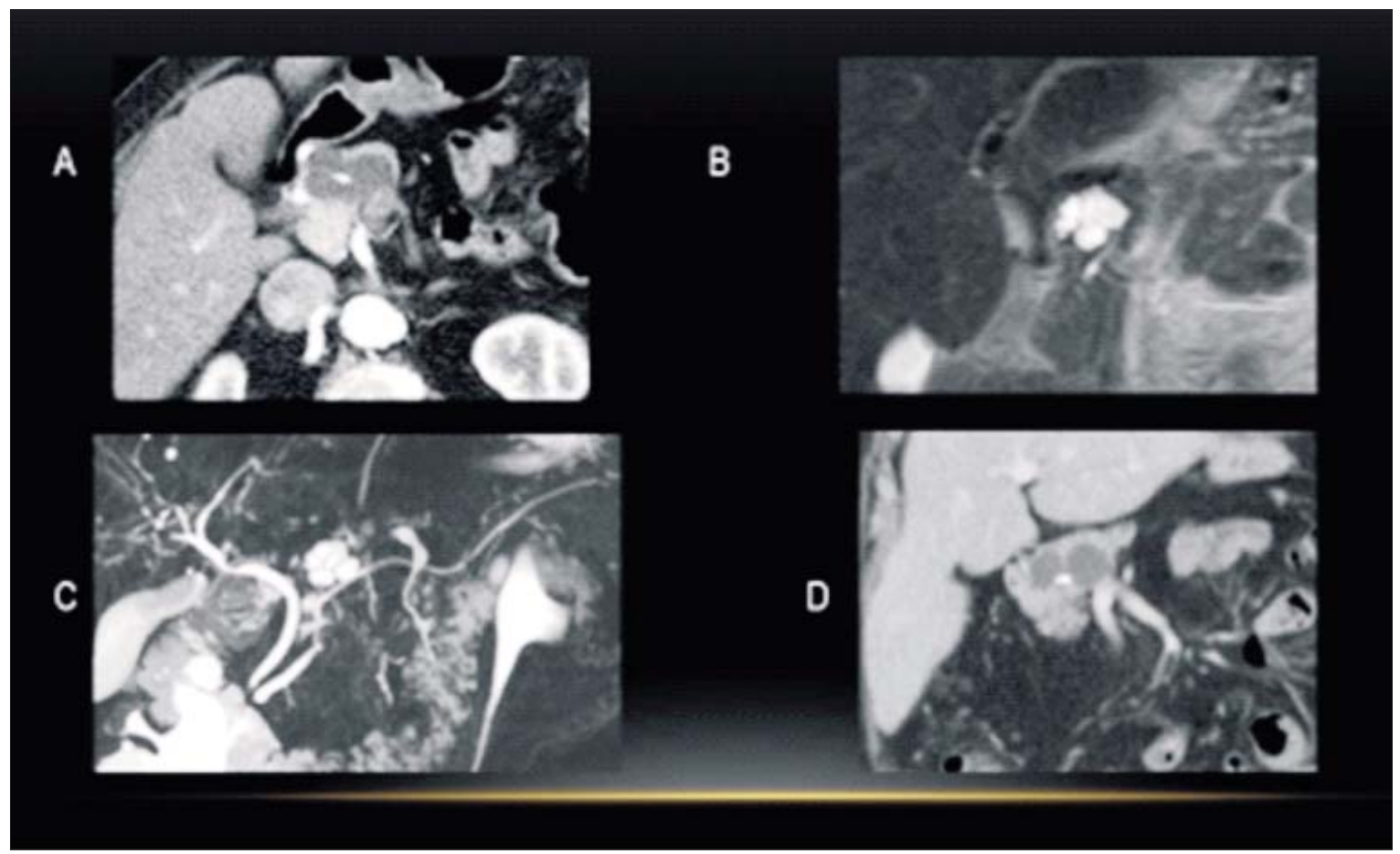

Figure 8. (A) Axial CT with contrast. Lobulated cystic lesion presenting a SCN typical calcified central scar. (B) MRI T2w confirms the cystic lesion with honeycomb-like multiple micro cysts separated by thin septa, and clearly delimited by a thin capsule; non-invasive behavior. (C) MRCP demonstrates extra ductal location; there is no communication with pancreatic duct. (D) MRI T1w, contrast. Confirms the benign nature; there are no solid components and no vascular infiltration

be characteristic and virtually pathognomonic $(28,30)$. Calcification is better depicted on CT (Fig. $8 \mathrm{~A}$ ). The presence of a large number of very small cysts delimited by enhancing septa may actually produce what may look like a solid appearance on $\mathrm{CT}(9,28)$. In these cases, clear depiction of numerous discrete small fluid-filled cysts at MRI (due to the high sensitivity of the method in detecting fluid) will usually facilitate correct diagnostic (Fig. 8 B) (28,29). Uncommonly, an SCN may have an oligolocular or macrocystic appearance and/or no central scar, which makes them difficult to differentiate from other mucinous forms of cystic neoplasms. In such cases, they may be over appreciated as malignant tumors (Figs. 9,10). However, if the pancreatic duct is not affected, the diagnosis is SCN. Note as well that SCN do not produce mucin. They are filled with a clear fluid and have a well-defined capsule.
Serous cystadenoma with pancreatic head localization may cause a certain degree of external compression on the terminal bile duct. However, jaundice cases are extremely rare. There are also rather rare reports of pancreatic duct dilatation compression induced (31).

\section{Treatment}

Given that malignant transformation of SCNs is extremely rare (risk, 0-1.2\%) (9,34), a conservative approach of surveillance imaging has been proposed as a logical therapeutic strategy $(28,30)$. This strategy remains a bit controversial, however, and has been challenged recently. The decrease in perioperative mortality after major pancreatic resections observed during the last two decades may account in part for the change of treatment policy toward a more aggressive approach with resection recommended for most (or even all) cystic neoplasms involving the body or tail 
of the pancreas (29). The rare but recently described "locally aggressive" SCN (which is characterized by local invasion, occurring in 5 $\%$ of patients) supports an aggressive approach of treatment; this subtype of unusual SCNs manifests an aggressive behavior, defined as local involvement of surrounding strictures (bile/pancreatic duct, extrahepatic venous system, etc.), and has the potential of distant (hepatic) metastases (32).

The growth rate is one of the factors that are being considered when deciding between follow-up and surgical treatment. El-Hayek et al. (33) showed in a study on 219 patients that growth rate of serous cystadenoma is better appreciated in terms of percentage increase of initial size per year, which normally remains constant, in contrast to measuring size change in $\mathrm{cm}$, which is exponential. They reported an overall growth rate of $6.2 \%$ per year. This correlates with the results of Malleo et al. (34), who measured growth in $\mathrm{cm}$ increase per year, and distinguished between an estimated mean growth of $0.1 \mathrm{~cm}$ increase per year in the first 7 years and of $0.6 \mathrm{~cm} /$ year after the first 7 years. The two mentioned studies suggest in agreement with other recent studies (35) that surgical treatment of SCNs should rather be based on accelerations in the growth pattern and/or development of symptoms, than on tumor size (Fig. 9). Although it remains unclear whether this increased rate of growth [size doubling time in less than 12 years (33)] has any impact on malignant potential (34,

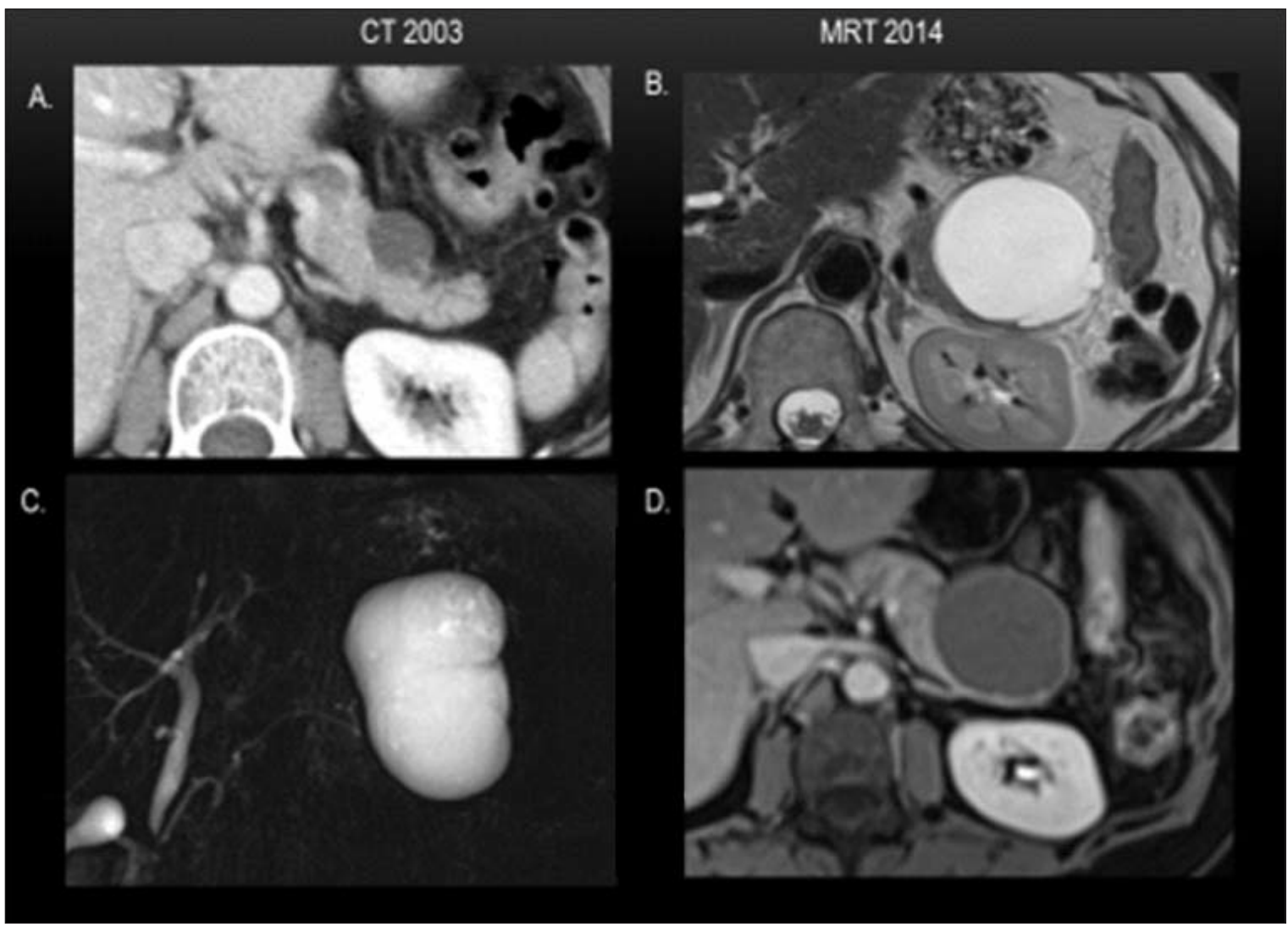

Figure 9. Long-term observation of a SCN. (A) Tumor size at the initial CT examination in 2003 is $2.0 \times 1.8 \mathrm{~cm}$. Neither central nor peripheral calcification present. No infiltration of the peripancreatic fat tissue. (B) Follow-up MRI examination 2014 shows tumor size increase to $5.2 \times 7.4 \mathrm{~cm}$. No septa or solid nodes present. (C) MRCP shows location outside the pancreatic duct. (D) No accumulation of i.v. administered contrast and no septa. Normal pancreatic tissue. No atrophy. Treatment / Diagnostic: US guided fine-needle aspiration of $25 \mathrm{ml}$ fluid showed no mucin, CEA negative, no tumor cells, low amylase activity and low viscosity. Final diagnostic: benign SCN 
36), an increased growth rate intuitively would increase the risk of the SCNs becoming symptomatic within the lifetime of many patients.

A conservative approach, however, can be considered in the vast majority of patients with SCN (e.g., in the presence of a small, asymptomatic lesion in the pancreatic head, especially in a frail or elderly patient), given the slow progression of these lesions over many years $(2,9,37)$. Indeed, in the study by Bassi et al. (38), 50 patients with SCN who were managed non-operatively had no evidence of a "significant increase in the diameter of the lesion" after a median follow-up of 69 months. Indeed, large $(\geq 4 \mathrm{~cm})$ SCNs are associated with a more than threefold increase in the likelihood of developing symptoms (9).
Currently, the accepted indications for operative intervention in patients with SCNs include (10) (Figs. 9, 10):

1. Presence of relevant symptomatology, which is usually due to local compression (not invasion) of surrounding structures.

2. Size $\geq 4 \mathrm{~cm}$, although some newer studies $(39,40)$ suggest size not being a relevant criterion, but growth pattern and presence of symptoms.

3. Rapid enlargement of a SCN or presence of an eccentric mass or pericystic infiltrative appearance such as biliary or pancreatic ductal obstruction (findings raising concerns about the presence of malignancy).

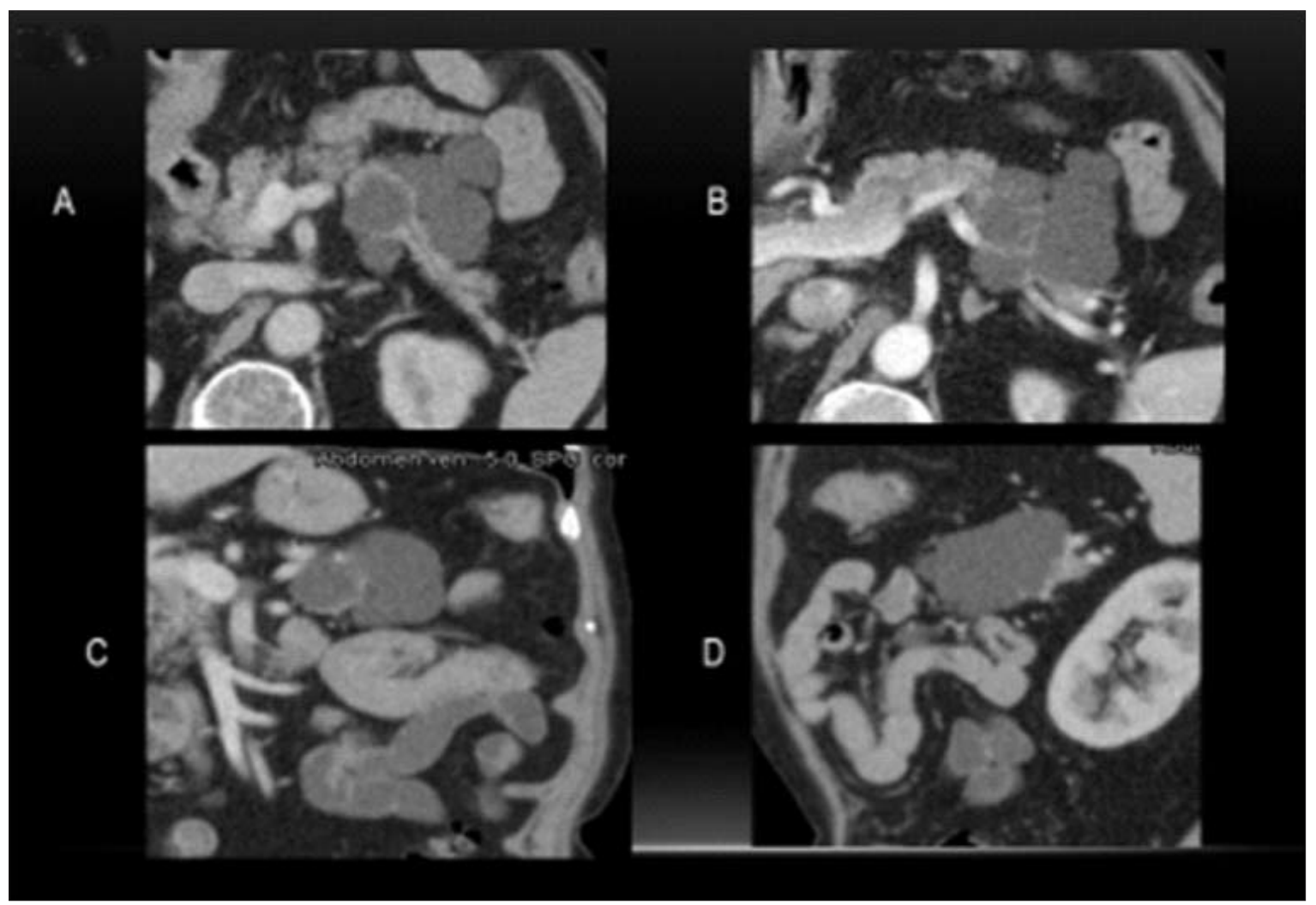

Figure 10. Multiple macrocysts in the pancreatic head and tail (A, B, C, D) which compress and infiltrate a. and v. lienalis (B). The lesion is located clearly outside the pancreatic duct. Based on rapid growth pattern of $8 \mathrm{~mm} /$ year and on impossibility of clear differential diagnostic to MCN, this lesion was surgically treated. Macrocystic lesions are difficult to differentiate from MCN, which justifies the treatment decision of left pancreas resection with splenectomy. Histological examination confirmed diagnosis of macrocystic SCN with no malignancy signs 
4. Uncertainty about the type of cystic neoplasm (SCN vs. MCN), despite the use of modern and sophisticated diagnostic tools (see above). Indeed, as sensitivity for the diagnosis of the potentially malignant mucinous neoplasms increases, the specificity decreases.

5. When a preoperative diagnosis cannot be established with a reasonable level of confidence, resection should be considered strongly. In this case, resection is often performed to avoid potential under treatment of an otherwise curable overt or premalignant neoplasm.

SCNs in a nutshell

- Only tumor which is NOT pre-malignant;

- Usually incidental detection on "granny";

- Microcysts filled with clear, serous fluid;

- May contain a central scar, which is sometimes calcified;

- Differentiation to IPMN: no communication with pancreatic duct;

- No need for resection if no symptoms present.

\section{Conclusion}

Serous cystadenoma are benign tumors, which needn't be resected on asymptomatic patients.

\section{References}

1. Gaujoux S, Brennan MF, Gonen M, D'Angelica MI, DeMatteo R, Fong $Y$, et al. Cystic lesions of the pancreas: changes in the presentation and management of 1,424 pacients at a single institution over a 15year time period. J Am Coll Surg. 2011;212(4):590-600; discussion 600-3. doi: 10.1016/j.jamcollsurg.2011.01.016.

2. Brugge WR, Lauwers GY, Sahani D, Fernandez-del Castillo C, Warshaw AL. Cystic neoplasms of the pancreas. N Engl J Med. 2004:351(12):1218-26.

3. Brugge WR. Diagnosis and management of cystic lesions of the pancreas. J Gastrointest Oncol. 2015;6(4):375-88. doi: 10.3978/ j.issn.2078-6891.2015.057.

4. Compagno J, Oertel JE. Microcystic adenomas of the pancreas (glycogenrich cystadenomas): a clinicopathologic study of 34 cases. Am J Clin Pathol. 1978;69(3):289-98.

5. Compagno J, Oertel JE. Mucinous cystic neoplasms of the pancreas with overt and latent malignancy (cystadenocarcinomas and cystadenomas): a clinicopathologic study of 41 cases. Am J Clin Pathol. 1978;69(6):573-80.

6. Lennon AM, Wolfgang C. Cystic neoplasms of the pancreas. J Gastrointest Surg. 2013;17(4):645-53. doi: 10.1007/s11605-0122072-6. Epub 2013 Jan 24.

7. Yoon WJ, Brugge WR. Pancreatic cystic neoplasms: diagnosis and management. Gastroenterol Clin North Am. 2012;41(1):103-18. doi: 10.1016/j.gtc.2011.12.016. Epub 2012 Jan 20.
8. Costa PRL, Meneses Rêgo AC, Araujo-Filho I. Pancreatic cystic lesions: classification, diagnosis and treatment. Int Surg J. 2016; 3(2):443-51.

9. Sakorafas GH, Smyrniotis V, Sarr MG (Eds.). Pancreatic cystic neoplasms: from imaging to differential diagnosis and management. Springer; 2015.

10. Correa-Gallego C, Ferrone CR, Thayer SP, Wargo JA, Warshaw AL, Fernández-Del Castillo C. Incidental pancreatic cysts: do we really know what we are watching? Pancreatology. 2010;10(2-3):144-50. doi: 10.1159/000243733. Epub 2010 May 17.

11. Cho CS, Russ AJ, Loeffler AG, Rettammel RJ, Oudheusden G, Winslow ER, et al. Preoperative classification of pancreatic cystic neoplasms: the clinical significance of diagnostic inaccuracy. Ann Surg Oncol. 2013;20(9):3112-9. doi: 10.1245/s10434-013-2986-6. Epub 2013 Apr 18.

12. Sahani DV, Kadavigere R, Saokar A, Fernandez-del Castillo C, Brugge WR, Hahn PF. Cystic pancreatic lesions: a simple imaging-based classification system for guiding management. Radiographics. 2005 25(6):1471-84.

13. Yoshioka M, Sato T, Furuya $T$, Shibata $S$, Andoh $H$, Asanuma $Y$, et al. Positron emission tomography with 2-deoxy-2-[(18)F] fluorod-glucose for diagnosis of intraductal papillary mucinous tumor of the pancreas with parenchymal invasion. J Gastroenterol. 2003 38(12):1189-93.

14. Clores MJ, Thosani A, Buscaglia JM. Multidisciplinary diagnostic and therapeutic approaches to pancreatic cystic lesions. J Multidiscip Healthc. 2014;7:81-91. doi: 10.2147/JMDH.S43098. eCollection 2014

15. Tanaka M, Fernández-del Castillo C, Adsay V, Chari S, Falconi M, Jang JY, et al. International consensus guidelines 2012 for the management of IPMN and MCN of the pancreas. Pancreatology. 2012 12(3):183-97. doi: 10.1016/j.pan.2012.04.004. Epub 2012 Apr 16.

16. Brugge WR. Approaches to the drainage of pancreatic pseudocysts. Curr Opin Gastroenterol. 2004;20(5):488-92.

17. Pitman MB, Lewandrowski K, Shen J, Sahani D, Brugge W, Fernandez-del Castillo C. Pancreatic cysts: preoperative diagnosis and clinical management. Cancer Cytopathol. 2010;118(1):1-13. doi: 10.1002/cncy.20059.

18. Turner BG, Brugge WR. Pancreatic cystic lesions: when to watch, when to operate, and when to ignore. Curr Gastroenterol Rep. 2010;12(2):98-105. doi: 10.1007/s11894-010-0097-0.

19. Bennett S, Lorenz JM. The role of imaging-guided percutaneous procedures in the multidisciplinary approach to treatment of pancreatic fluid collections. Semin Intervent Radiol. 2012;29(4):314-8. doi: 10.1055/s-0032-1330066.

20. Giovannini M. Endoscopic ultrasonography-guided pancreatic drainage. Gastrointest Endosc Clin N Am. 2012;22(2):221-30, viii. doi: 10.1016/i.giec.2012.04.004.

21. Samuelson AL, Shah RJ. Endoscopic management of pancreatic pseudocysts. Gastroenterol Clin North Am. 2012;41(1):47-62. doi: 10.1016/i.gtc.2011.12.007. Epub 2012 Jan 5.

22. Acar M, Tatli S. Cystic tumors of the pancreas: a radiological perspective. Diagn Interv Radiol. 2011;17(2):143-9. doi: 10.4261/13053825.DIR.3254-09.1. Epub 2010 Jul 15.

23. Kalb B, Sarmiento JM, Kooby DA, Adsay NV, Martin DR. MR imaging of cystic lesions of the pancreas. Radiographics. 2009;29(6):1749-65. doi: 10.1148/rg.296095506.

24. Wang Y, Miller FH, Chen ZE, Merrick L, Mortele KJ, Hoff FL, et al. Diffusion-weighted MR imaging of solid and cystic lesions of the pancreas. Radiographics. 2011;31(3):E47-64.

25. Visser BC, Yeh BM, Qayyum A, Way LW, Mc-Culloch CE, Coakley FV. Characterization of cystic pancreatic masses: relative accuracy of CT and MRI. AJR Am J Roentgenol. 2007;189(3):648-56.

26. Sakorafas GH, Smyrniotis V, Reid-Lombardo KM, Sarr MG Primary pancreatic cystic neoplasms revisited. Part III. Intraductal papillary mucinous neoplasms. Surg Oncol. 2011;20(2):e109-18. doi: 10.1016/j.suronc.2011.01.004. Epub 2011 Mar 10.

27. Sakorafas GH, Smyrniotis V, Reid-Lombardo KM, Sarr MG. Primary pancreatic cystic neoplasms revisited: part II. Mucinous cystic 
neoplasms. Surg Oncol. 2011;20(2):e93-101. doi: 10.1016/ j.suronc. 2010.12.003. Epub 2011 Jan 19.

28. Sakorafas GH, Smyrniotis V, Reid-Lombardo KM, Sarr MG. Primary pancreatic cystic neoplasms revisited. Part I: serous cystic neoplasms. Surg Oncol. 2011;20(2):e84-92. doi: 10.1016/ j.suronc.2010.12.002. Epub 2011 Jan 14.

29. Khan A, Khosa F, Eisenberg RL. Cystic lesions of the pancreas. AJR Am J Roentgenol. 2011;196(6):W668-77. doi: 10.2214/ AJR.10.4378.

30. Macari M, Megibow AJ. Focal cystic pancreatic lesions: variability in radiologists' recommendations for follow-up imaging. Radiology. 2011;259(1):20-3. doi: 10.1148/radiol.11102437.

31. Hruban RH, Pitman MB, Klimstra DS. Tumors of the Pancreas. Atlas of Tumor Pathology. American Registry of Pathology, Vol 6. 2007.

32. Khashab MA, Shin EJ, Amateau S, Canto MI, Hruban RH, Fishman EK, et al. Tumor size and location correlate with behavior of pancreatic serous cystic neoplasms. Am J Gastroenterol. 2011;106(8):1521-6. doi: 10.1038/ajg.2011.117. Epub 2011 Apr 5.

33. El-Hayek KM, Brown N, O'Rourke C, Falk G, Morris-Stiff G, Walsh RM. Rate of growth of pancreatic serous cystadenoma as an indication for resection. Surgery. 2013;154(4):794-800; discussion 800-2. doi: 10.1016/j.surg.2013.07.005.

34. Malleo G, Bassi C, Rossini R, Manfredi R, Butturini G, Massignani M, et al. Growth pattern of serous cystic neoplasms of the pancreas: observational study with long-term magnetic resonance surveillance and recommendations for treatment. Gut. 2012;61(5):746-51. doi: 10.1136/gutjnl-2011-300297. Epub 2011 Sep 22.

35. Galanis C, Zamani A, Cameron JL, Campbell KA, Lillemoe KD, Caparrelli $D$, et al. Resected serous cystic neoplasms of the pancreas: a review of 158 patients with recommendations for treatment. J Gastrointest Surg. 2007;11(7):820-6.

36. Strobel 0, Z'graggen K, Schmitz-Winnenthal FH, Friess H, Kappeler A, Zimmermann A, et al. Risk of malignancy in serous cystic neoplasms of the pancreas. Digestion. 2003;68(1):24-33. Epub 2003 Aug 29.

37. Fernández-del Castillo $\mathrm{C}$, Targarona J, Thayer SP, Rattner DW, Brugge WR, Warshaw AL. Incidental pancreatic cysts: clinicopathologic characteristics and comparison with symptomatic patients. Arch Surg. 2003;138(4):427-3; discussion 433-4.

38. Bassi C, Salvia R, Molinari E, Biasutti C, Falconi M, Pederzoli P. Management of 100 consecutive cases of pancreatic serous cystadenoma: wait for symptoms and see at imaging or vice versa? World J Surg. 2003;27(3):319-23. Epub 2003 Feb 27. 